\title{
Pelleting Vineyard Pruning at Low Cost with a Mobile Technology
}

\author{
Giuseppe Toscano ${ }^{1}$, Vincenzo Alfano ${ }^{2, *}$, Antonio Scarfone ${ }^{2}$ and Luigi Pari ${ }^{2}(\mathbb{C}$ \\ 1 Department of Agriculture, Università Politecnica delle Marche, 60131 Ancona, Italy; \\ g.toscano@staff.univpm.it \\ 2 Consiglio per la ricerca in agricoltura e l'analisi dell'economia agraria (CREA), Centro di Ricerca Ingegneria \\ e Trasformazioni agroalimentari, Via della Pascolare, 16, Monterotondo, 00015 Roma, Italia; \\ antonio.scarfone@crea.gov.it (A.S.); luigi.pari@crea.gov.it (L.P.) \\ * Correspondence: vincenzo.alfano@crea.gov.it; Tel.: +39-06-906-753-15
}

Received: 7 August 2018; Accepted: 14 September 2018; Published: 18 September 2018

check for updates

\begin{abstract}
The goal of this work was to test a patented pruning harvester and a mobile pelleting system specifically designed for the vineyard agripellet chain. Biomass was characterized before and after storage and after the pelleting stage. The performance, the fuel consumption, and the work quality of the harvester were assessed together with the productivity and the power consumption of the mobile pelleting system. Production costs of pellet were estimated for the whole logistic chain, considering two scenarios: Storage and pelleting directly at the farm site or at a dedicated location at variable distance from the fields. For comparison, the direct production of chips without pelleting was considered. Results indicate that harvester performance was quite good and comparable with commercial solutions; the chips produced exhibited excellent storage performance, allowing direct pelleting without forced drying; the pellet quality was good comparable with that produced from forestry biomass. From an economic point of view, in-field pelleting was the most cost-effective solution, with a good margin of profit up to $57 € \mathrm{t}^{-1}$; on the other hand, when transport to an intermediate storage center is necessary, profit margin reduces gradually and fades off at an average $50 \mathrm{~km}$ distance from the fields.
\end{abstract}

Keywords: agripellet; biomass; bioenergy; mobile pelleting plant; logistic chain; pruning harvester

\section{Introduction}

There is a growing interest in renewable energy sources because of the increasing price of fossil fuels and the related environmental concerns due to greenhouse gas emissions (GHG) [1]. Sustainable energy production can foster the neutral balance of GHG, especially when sources, such as lignocellulosic biomass, are highly available and their procurement does not interfere with food chains [2].

Bioenergy has a primary role in achieving the target set in the national Renewable Action Plans (nREAPs), accounting for almost $54.5 \%$ of the final energy consumption in Europe [3]. Solid biomass used for electricity, heating, and cooling production is the biggest source of renewable energy in the European Union (EU) and is considered key to achieving the 2020 renewable energy targets [4].

First generation biofuels, made from edible biomass (vegetable oils, cereals, beets, and sugar cane), raise several ethical and social issues. A solution that helps to avoid food/non-food competition is the use of lignocellulosic biomass, agroindustrial wastes, and agricultural residues [5].

Moreover, the sustainability of the production of biofuels and their availability became, in recent years, an object of debate and are still in the spotlight for the EU. Recently, the European Commission (EC) has revised the Renewable Energy Directive (RED), extending the sustainability criteria to solid 
and gaseous biomass fuels used for heat and power production [6].The level of attention to sustainable production is also high because the demand for renewable energy is expected to increase remarkably in the next years. In fact, especially for biomass, scientists stress that traditional sources for bioenergy production would not be enough to meet future energy needs and to respond to the new targets of the EU 2030 framework for climate and energy policies [7,8]. This implies the need to find alternative and sustainable ways to obtain lignocellulosic material to be exploited. In this regard, an interesting option is given by the agricultural residues or the byproducts and wastes from the agroforest and agroindustrial sectors [9].

Among the agricultural residues, pruning is considered an important biomass resource, because of its large availability in Europe [10]. In Italy, a large quantity of pruning derives from vineyards, a source of biomass that has already attracted the interest of scientists for both availability aspects and fuel characteristics [11]. Vineyards are grown over 3.2 million ha in Europe [12], of which 725,000 ha are in Italy, according to national statistics [13], resulting in high pruning biomass potential [14]. However, this biomass source is minimally exploited because of its low energy density and its poor suitability for direct utilization in small size plants. These limits in turn impede the growth of an optimized logistic chain focused on biomass pruning [10]. On the other hand, the densification process could represent a way to overcome these obstacles, furnishing high energy density products, which are easier to be managed and suitable for domestic heating systems. In 2013, Picchi et al. [11] showed that vineyard pruning is suitable for pellet production and for combustion in small-scale boilers. Moreover, the ISO 17225-1:2014 standard classifies vineyard pruning as woody biomass with code 1.1.7, namely "Segregated wood from gardens, parks, roadside maintenance, vineyards, fruit orchards, and driftwood from freshwater" and, according to ISO 17225-6:2014, such a biomass could be utilized to produce pellet defined as non-woody, which commonly takes the name of agripellet $[15,16]$.

However, the harvesting and transport costs and the low quality of the material represent difficult obstacles to overcome [17]. The machines commonly used to collect pruning derive from conventional mulchers or shredders; these machines work fast, as they were conceived to clean up the fields rapidly and to limit fuel consumption; subsequently, the harvested products obtained have low quality characteristics in terms of storability, chip particle size, and inert contaminations. These are crucial characteristics in the post-harvest stages of the energy production chain [18]. To solve this problem, this work proposes an assessment of an innovative supply and production chain from harvest to pellet generation. The approach includes innovative machines and practical handholds for farmers, aimed at optimizing the quality of the product and the costs for production. The harvest was performed using a vineyard pruning harvester designed to preserve the quality of the fuel, while for densification a mobile milling-pelleting system was used to produce pellets directly at the farm site. This approach allowed the production of vineyard pruning chips that, after a period of open-air storage, were directly milled and pelletized in the storage site.

The goal of this work is to demonstrate the validity of the system through the evaluation of the performance of the machines and the quality of the agripellet produced together with an economic assessment of the production process.

The economic comparison with the commercial pellet is not finalized to compare a local versus an industrial chain, but to have reference parameters for quantifying the economic value of a new product. This was done to emphasize the economic sustainability of the short chain in the absence of the agripellet market, as shown by the results of the Pellets for Europe project developed in the Framework of the ALTENER Programme [19].

\section{Materials and Methods}

The work was divided into two phases, namely phase 1 - pruning harvest and phase 2 -pelleting. The activities were carried out between February and September 2016 around the municipalities of Illasi (Province of Verona) and Breda del Piave (Province of Treviso) in the Veneto Region (NE Italy). 


\subsection{Phase 1-Pruning Harvest}

Pruning was harvested from a 30-year-old vineyard, variety Garganeca, located at Illasi, on a flat land, drip irrigated and with medium texture soil characteristics. The planting system was $4 \mathrm{~m}$ among rows and $0.8 \mathrm{~m}$ along the row, while the training system was a tendon.

Before the test, all plants were pruned manually, making sure to drop the cut part in the middle of the inter-row, forming an ordered windrow within each inter-row space. Then, the windrows were characterized, taking the mean width and height, respectively.

The machine used for the test is a patented pruning harvester, manufactured by Costruzioni Nazzareno, MAREV Alba 150 model, towed by a tractor Goldoni, model 70 Star with $50 \mathrm{~kW}$ power (Figure 1). The harvester has $1550 \mathrm{~mm}$ width, $3850 \mathrm{~mm}$ length, $1750 \mathrm{~mm}$ height, and a total weight of 2.8 tons. Frontally, the harvester has a pick up system formed by two overlapping rotors. The lower rotor has a length of $1500 \mathrm{~mm}$, corresponding to the real working width of the machine. The rotor includes two converging augers, equipped with metal teeth, designed in a way to ensure the catchment, the conveying, and the lift of soil-free pruning from the ground. The upper rotor has a length of $1 \mathrm{~m}$ and is formed by ten lines of star-shaped disks. Each disk has eight tilted teeth, which push the biomass toward the chipping system. The chipping system is formed by a rotor equipped with special knives; it provides a net cut of the pruning and avoids the formation of shredded material. Details of chipping systems of different pruning harvesters, including the MAREV Alba 150 model, are furnished separately [20]. The presence of shredded fine particles in the stored wood chip piles tends to occlude the air spaces among chips, limiting air circulation and slowing down the dying process of the biomass. The persistence of moisture in wood chip worsens remarkably the storage performance of the biomass and promotes microbial degradation, as demonstrated by Pari et al. (2017) [21]. The chipped material is blown in a $3 \mathrm{~m}^{3}$ bin (configuration for tendon trained vineyard) through a mechanic propulsion system similar to a tangential fan, formed by eight metal plates. The bin can reach $3 \mathrm{~m}$ height by means of a hydraulic pantograph in order to discharge the material. An $8 \mathrm{~m}^{3}$ trailer was utilized to transport the chipped material to the storage site.

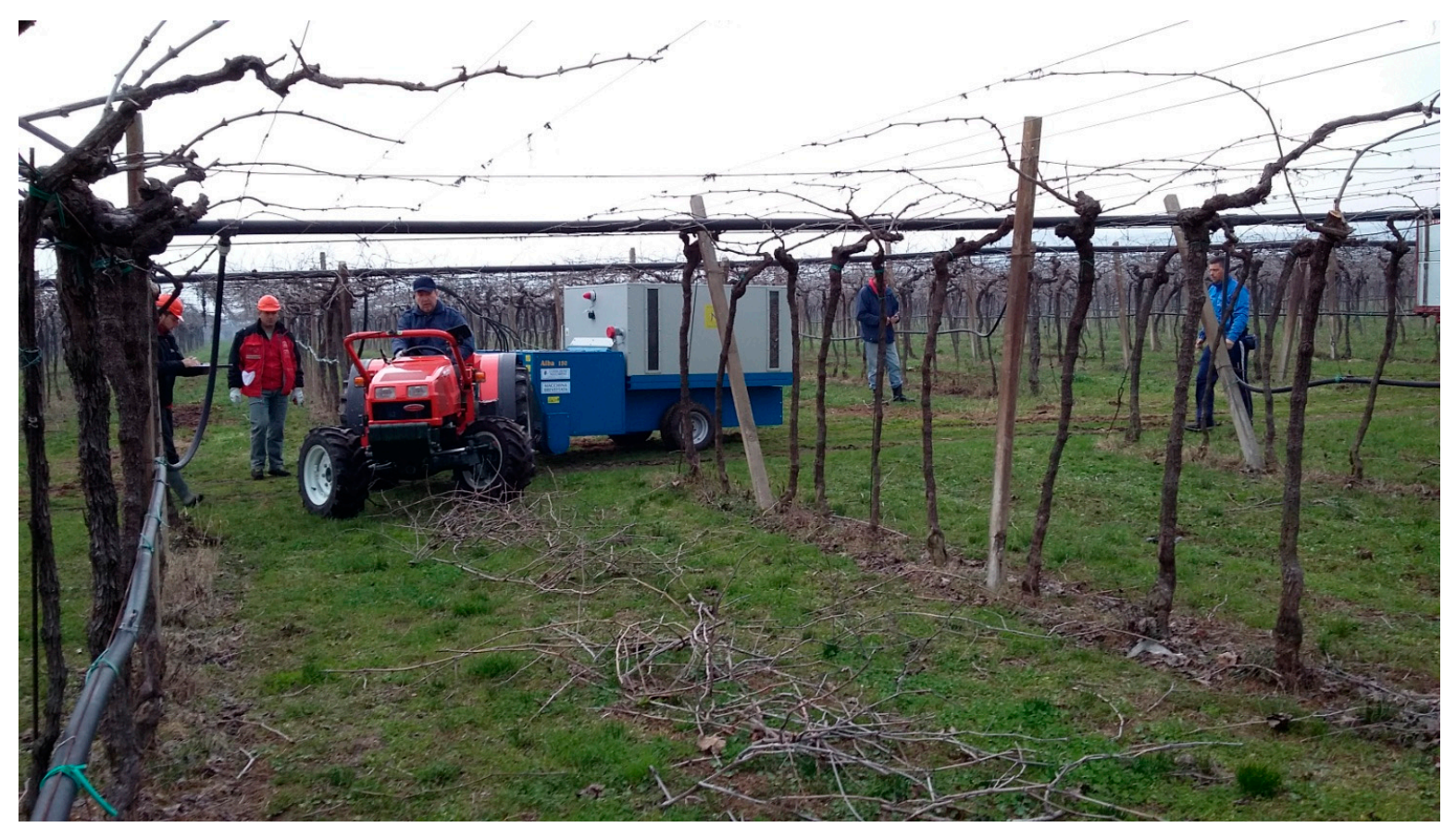

Figure 1. Pruning harvester manufactured by Costruzioni Nazzareno, MAREV Alba 150 model. 


\subsubsection{Evaluation of the Harvest Performance}

The machine was tested on three replicated harvest test areas (blocks), created considering six pruning windrows for each block over a total surface of 0.74 ha. The performance was evaluated through the study of the working times according to the methodology adopted by the Commission Internationale de l'Organisation Scientifique du Travail en Agriculture (CIOSTA) and the Italian Society of Agricultural Engineering (AIIA) [22]. The main working times were: $\mathrm{TO}=$ total operating time, as sum of $\mathrm{TE}=$ effective operative time $(\%$ of operating time, $\mathrm{TO})$, and $\mathrm{TA}=$ accessory time $(\%$ of operating time, $\mathrm{TO}$ ).

Accessory time included the time for turning, refueling, unloading, and maintenance. Other working parameters were field efficiency (\%), theoretical and effective speed $\left(\mathrm{m} \mathrm{s}^{-1}\right)$, theoretical and effective field capacity $\left(\right.$ ha $\left.\mathrm{h}^{-1}\right)$, working productivity $\left(\mathrm{t}^{-1}\right)$.

The fuel consumption of the tractor was measured during the total operating work (including turning, unloading, rest, and machine regulations), through machine tank refilling until full level at the end of each block, using a graduated large cylinder.

Field biomass availability per hectare was calculated weighing the material obtained in each block (three replicates), using a tractor trailer and a certified weighbridge. Biomass losses due to the faults of the machine pick up were assessed by weighting the product left on the ground in six replicated plots of $10 \mathrm{~m}^{2}$ randomly selected within the experimental field.

\subsection{Phase 2-Pelleting}

The test took place at the Costruzioni Nazzareno factory in Breda del Piave. The material was transferred to this location after an open-air storage period lasting eight months where it was harvested. Before pelleting, the moisture content was detected according to UNI EN 18134-1:2015 technical standard, in order to verify that the water content after storage was below $20 \%$ to allow such processing [23].

A mobile plant for pruning biomass densification, developed by Costruzioni Nazzareno, was utilized (Figure 2).

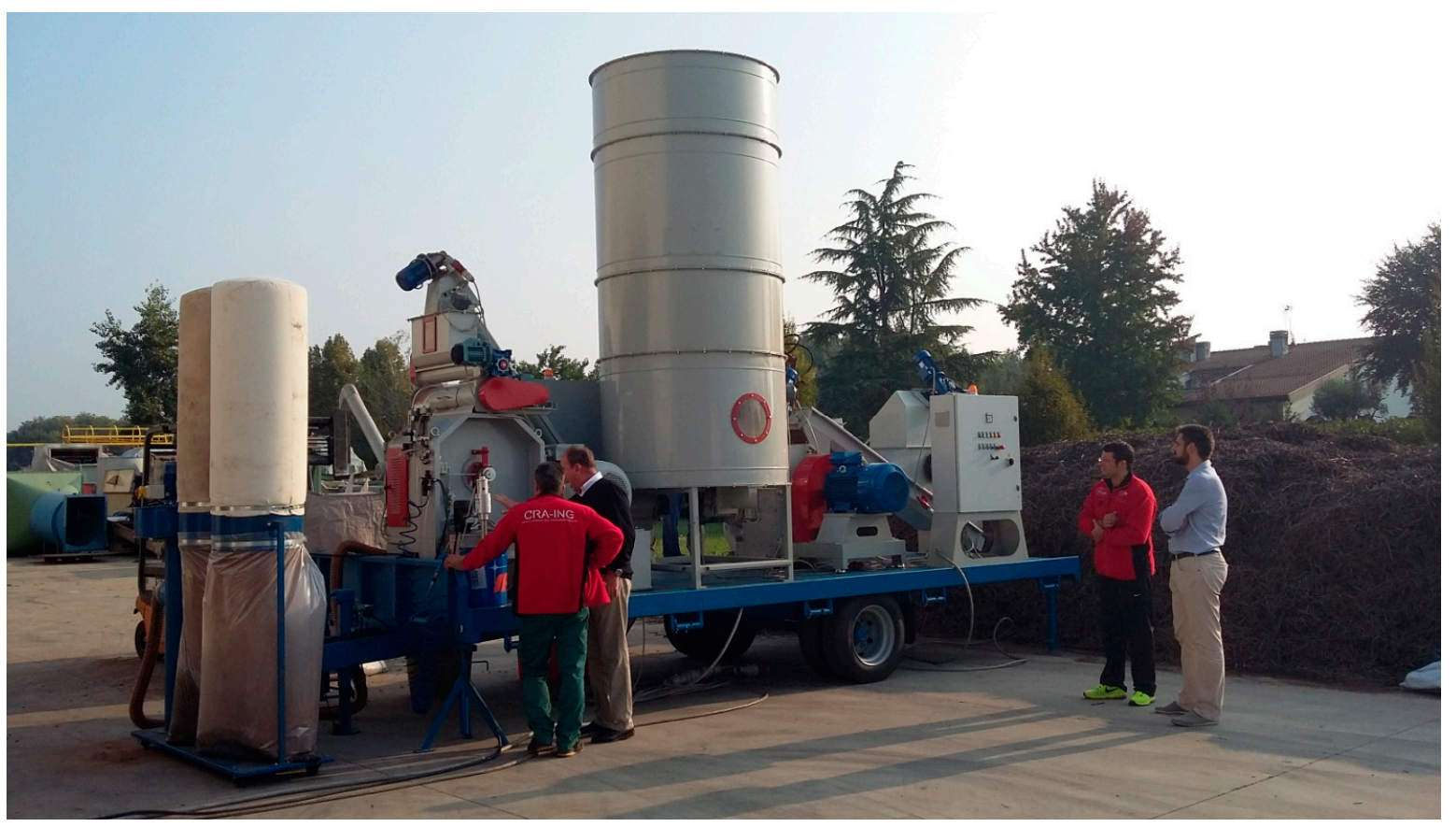

Figure 2. Mobile pelleting plant developed by Costruzioni Nazzareno.

The main elements of the system are the grinding mill, a $3 \mathrm{~m}^{3}$ buffer tank for the accumulation of the milled material, and the pelleting system. The three elements are connected by means of pipes 
of suitable diameter through which the material is moved by a pneumatic system. All the elements are mounted on a trailer for road transport, in order to process the material directly on the field or at the dedicated farm structures. The loading of the biomass into the hopper is performed manually or mechanically. From here, a conveyor system transports the material to the refining mill that pulverizes the material until the particle size suitable for densification is obtained. An electric fan pushes the material inside the buffer tank, equipped with a filter to reduce dust emissions, where it is stirred by a flywheel. Successively, the material is transported to the press of the pelleting system. The pelletizer has a $6 \mathrm{~mm}$ diameter extruder, while the grinding mill has a grid of $1 \mathrm{~mm}$. Both the grinding mill and the pelleting system are powered by a $35 \mathrm{~kW}$ electric engine.

\subsubsection{Pelleting Performance}

Productivity was assessed by weighing the pellet produced in one minute and repeating the measure 20 times randomly during the test. Moreover, the quantity of pellet produced in 20 consecutive minutes was weighed to validate the results.

In order to evaluate the power absorbed by the load, a current clamp was utilized to measure the line current.

Assuming a perfectly balanced three-phase power system (in a four-wire star-connected load), the total power is equal to three times the power absorbed by one phase, according to the equation:

$$
P_{t}=3 \cdot V_{f} \cdot I_{f} \cdot \cos \varphi
$$

where $V_{f}$ and $I_{f}$ are respectively the phase voltage and current, and $\cos \varphi$ is the power factor.

For star-connected circuits:

$$
V_{l}=\sqrt{3} \cdot V_{f} \text { and } I_{l}=I_{f}
$$

where $V_{l}$ and $I_{l}$ are respectively line voltage and current.

Considering the best power factor correction, $\cos \varphi=0.9$ :

$$
P_{t}=3 \cdot \frac{V_{l}}{\sqrt{3}} \cdot I_{l} \cdot \cos \varphi=\sqrt{3} \cdot V_{l} \cdot I_{l} \cdot 0.9
$$

The current clamp display was recorded during the whole test. MPlayer software (1.3.0 version) a free and open media player, was used to automatically obtain a screen shot every $10 \mathrm{~s}$, in order to read and average the measures.

\subsection{Biomass Characterization}

Biomass quality was assessed before the passage of the harvest machine (fresh pruning), after collection (fresh chips), after storage (dry chips), and after pelleting (pellet). In particular, five samples of fresh pruning and pellet were analyzed to determine the main fuel quality parameters, as summarized in Table 1. Fresh chips were exclusively characterized with respect to particle size distribution (before storage), moisture content, and bulk density (before and after storage). For moisture content and bulk density of chips, the same reference standard was used, as indicated in Table 1. On the other hand, for particle size analysis, five samples of 4-liter volume each were weighed and successively divided into four dimensional classes ( $<50 \mathrm{~mm}$, among $50-100 \mathrm{~mm}, 100-120 \mathrm{~mm},>120 \mathrm{~mm}$ ). Then, the product of each dimensional class was weighed again for defining the percent incidence of each class on total sample weight. Meanwhile, a visual inspection of the material allowed the assessment of the quality of the cut and the cleanliness, by searching for foreign bodies such as soil or stones.

For the laboratory analysis, five samples of about $1500 \mathrm{~g}$ each of pruning and pellet were placed in non-breathable bags, sealed, and delivered to the Biomass Lab of Marche Polytechnic University. After the determination of parameters on fresh basis, the samples were oven dried at $105 \pm 2{ }^{\circ} \mathrm{C}$ 
temperature until they reached constant weight, then milled with the Cutting Mill Retsch Sm 100, and finally sieved through a $1 \mathrm{~mm}$ mesh.

Table 1. Parameters analyzed on biomass according to the reference standards and technical procedures.

\begin{tabular}{|c|c|c|}
\hline Parameter & Standard & Procedure \\
\hline Moisture content & ISO 18134-1:2015 & Samples were dried at $105^{\circ} \mathrm{C}$ in forced ventilation oven. \\
\hline Ash content & ISO 18122:2015 & $\begin{array}{l}\text { Samples were determined by a thermo-gravimetric analyzer (TGA leco } \\
\text { Mod. 701). }\end{array}$ \\
\hline Mechanical durability & UNI EN 15210-1 & $\begin{array}{l}\text { The sample was subjected to controlled shocks by collision of pellet } \\
\text { against each other and against the wall of a rotating chamber. }\end{array}$ \\
\hline Bulk density & UNI EN 15103 & $\begin{array}{l}\text { A standard container was filled with the portion of a given size and shape } \\
\text { and weighted afterward. }\end{array}$ \\
\hline Net calorific value & UNI EN 14918 & $\begin{array}{l}\text { An isoperibolic calorimeter (mod. C2000 basic, IKA) was used to } \\
\text { determine gross calorific value. The net calorific value was determined } \\
\text { starting from gross calorific value, water and hydrogen contents of the } \\
\text { analytical sample. }\end{array}$ \\
\hline Nitrogen & ISO 16948:2015 & The determination was done by a Perkin Elmer CHN analyzer. \\
\hline Sulphur and Chlorine & ISO 16994:2015 & $\begin{array}{l}\text { Sulphur and chlorine contents were measured by decomposition in } \\
\text { calorimetric bomb with excess of oxygen and absorption of acid } \\
\text { combustion gases in water. Detection of sulphate and chloride was } \\
\text { performed by liquid ion chromatography (mod. 761 COMPACT } \\
\text { IC; Metrohm). }\end{array}$ \\
\hline Minor elements 1 & ISO 16968:2015 & $\begin{array}{c}\text { The chemical analysis provided for the digestion of the biomass sample in } \\
\text { a closed container, using a mixture of acids (HNO3/H2O2/HF) and } \\
\text { microwave oven (mod. Multiwave 3000; Anton Paar, Graz, Austria). } \\
\text { The mineralization product was then analyzed by inductively coupled } \\
\text { plasma optical emission spectrometry (ICP-OES mod. } \\
\text { Optima 2100; PerkinElmer). }\end{array}$ \\
\hline Ash melting behaviour & $\begin{array}{l}\text { UNI CEN/TS } \\
15370\end{array}$ & $\begin{array}{l}\text { The determination was done by an ash fusibility analyzer (SYLAB-model } \\
\qquad \text { IF } 1600 \mathrm{~F} \text { ). }\end{array}$ \\
\hline
\end{tabular}

${ }^{1} \mathrm{~Pb}, \mathrm{Cr}, \mathrm{Cu}, \mathrm{Mn}, \mathrm{Ni}, \mathrm{As}, \mathrm{Cd}, \mathrm{Hg}, \mathrm{Zn}$.

\subsection{Economic Assessment}

\subsubsection{Economic Scenarios}

Three scenarios were assessed (Table 2). Two possible pruning pellet production chains were identified, corresponding to Scenario (A): Storage and pelleting directly at the farm site, and Scenario (B): Storage and pelleting outside the farm in a centralized processing site. The first scenario is reliable in presence of large-scale farms with enough biomass and suitable infrastructures (storage yard, machineries for biomass handling, electric power availability). On the contrary, the second scenario occurs when intermediate storage is needed to gather pruning from several smaller farms in a centralized site. In this second scenario, aside from the pelleting cost, the goal of the study was to also determine the transport costs and the maximum distance at which biomass pelleting would be economically profitable.

Alternatively to pellet production, a third scenario with the utilization of pruning chips directly in a biomass plant (Scenario C) was considered; also in this case, the transport cost and threshold distance were assessed, as in Scenario B.

Summarizing, regarding the cost allocation, Scenario A includes the cost of harvest pruning and pelleting, Scenario B includes the cost of harvesting the pruning, transporting the chips, and pelleting, while Scenario $C$ includes only the cost of harvesting the pruning and transporting the chips.

A reference market price of commercial pellets and chips was utilized to estimate the profitability of the three chains. According to the solid biofuels price list of the Chambers of Commerce of Milan referring to February 2015 [24], the reference price used for pellet was $210 € \mathrm{t}^{-1}$ (for a purchase of a full cargo truck of A2 classified pellets in $15 \mathrm{~kg}$ bags, VAT excluded, without transport), while the 
reference price for chips was identified as $50 € \mathrm{t}^{-1}$ (referred to biomass obtained from forest maintenance operation, for a purchase of a full cargo truck, VAT excluded, without transport).

Table 2. Economic scenarios: Two possible pruning pellet production chains and direct use of chips.

\begin{tabular}{cccccc}
\hline Scenario & Harvesting & In field Drying & Transport & Drying & Pelleting \\
\hline A & Harvesting & In field drying & - & - & In field pelleting \\
\hline B & Harvesting & - & $\begin{array}{c}\text { Transport to intermediate } \\
\text { storage and processing site }\end{array}$ & Drying & Pelleting at processing site \\
\hline C & Harvesting & - & $\begin{array}{c}\text { Transport to biomass plant for } \\
\text { direct use }\end{array}$ & - & - \\
\hline
\end{tabular}

\subsubsection{Cost Estimation}

The estimation of the costs was conducted according to the methodology proposed by CRPA-Centro Ricerche Produzioni Animali in 2015 [25], with the assumptions showed in Table 3 (harvesting costs), Table 4 (transport costs), and Table 5 (pelleting costs). Concerning the harvesting and pelleting systems, ownership costs were calculated according to the data provided directly by the owners (purchasing cost, service life, resale), while operating costs were based on data directly measured during the field test: Fuel consumption $\left(\mathrm{l} \mathrm{h}^{-1}\right)$, effective field capacity $\left(\right.$ ha $\left.\mathrm{h}^{-1}\right)$, and material capacity $\left(\mathrm{t} \mathrm{h}^{-1}\right)$ of the harvesting system, according to Section 2.1.1, and productivity and power consumptions of the pelleting system, according to Section 2.2.1.

The costs for drying were neglected because in all cases it was performed in open air without investing in any infrastructure or covering system.

Table 3. Harvesting cost data.

\begin{tabular}{cccc}
\hline Parameter & Unit & Tractor & MAREV Alba 150 \\
\hline Power & $\mathrm{kW}$ & 50 & - \\
Investment & $€$ & 28,000 & 24,000 \\
Service life & year & 15 & 8 \\
Resale & $\%$ & 25 & 10 \\
Interest rate & $\%$ & 4 & 4 \\
Insurance & $\%$ & 0.25 & 0.25 \\
Labor & $€ \mathrm{~h}^{-1}$ & 12 & - \\
Fuel cost & $€ \mathrm{~L}^{-1}$ & 0.86 & - \\
Fuel consumption & $1 \mathrm{~h}^{-1}$ & 3.64 & - \\
Repair factor & $\%$ & 40 & 40 \\
Maintenance factor & $\%$ & 10 & 5 \\
\hline
\end{tabular}

For the cost of transport, a medium power tractor $(100 \mathrm{~kW})$ and a $40 \mathrm{~m}^{3}$ trailer, commonly used for agricultural practices, were considered (Table 4). The unitary cost $\left(€ \mathrm{t}^{-1} \mathrm{~km}^{-1}\right)$ was estimated by considering the hourly cost of the transport system, the bulk density of biomass measured in the field (Section 2.3), the load capacity of the trailer, and the travel speed of $40 \mathrm{~km} \mathrm{~h}^{-1}$. The equation used is the following: [Hourly cost $\left(€ \mathrm{~h}^{-1}\right) /$ Load capacity $\left.(\mathrm{t})\right] \times$ [Distance $(\mathrm{km}) /$ Speed $\left(\mathrm{km} \mathrm{h}^{-1}\right)$ ].

To determine the threshold distance for the transport of chips that would guarantee a profit margin, a calculation was done considering a depreciation of the A2 pellet price of $10 \%$, due to the lower quality of biomass ( $189 € \mathrm{t}^{-1}$ instead of $210 € \mathrm{t}^{-1}$ ), and a minimum profit margin of $30 € \mathrm{t}^{-1}$ for the product sold. This conservative approach has been adopted to display with a good margin of safety the maximum distance of transport of chips without incurring in overestimations. 
Table 4. Transport cost data.

\begin{tabular}{cccc}
\hline Parameter & Unit & Tractor & Trailer \\
\hline Power & $\mathrm{kW}$ & 100 & - \\
Load capacity & $\mathrm{m}^{3}$ & - & 40.0 \\
Investment & $€$ & 78,000 & 25,000 \\
Service life & year & 10 & 15 \\
Resale & $\%$ & 20 & 10 \\
Annual usage & $\mathrm{h}$ & 800 & 250 \\
Interest rate & $\%$ & 4 & 4 \\
Insurance & $\%$ & 0.25 & 0.25 \\
Labor & $€ \mathrm{~h}^{-1}$ & 12 & - \\
Fuel consumption & $€ \mathrm{~h}^{-1}$ & 14.0 & \\
Repair factor & $\%$ & 40 & 15 \\
Maintenance factor & $\%$ & 10 & 5
\end{tabular}

Table 5. Pelleting cost data.

\begin{tabular}{cccc}
\hline Parameter & Unit & Mill & Pelletizer \\
\hline Installed power & $\mathrm{kW}$ & 35 & 35 \\
Investment & $€$ & 10,000 & 60,000 \\
Service life & year & 8 & 15 \\
Resale & $\%$ & 20 & 10 \\
Interest rate & $\%$ & 4 & 4 \\
Price of electricity & $€ \mathrm{~kW}$ & 0.17 & 0.17 \\
Labor & $\mathrm{h}^{-1}$ & & 12 \\
Repair factor & $\% \mathrm{~h}^{-1}$ & 12 & 20 \\
Maintenance factor & $\%$ & 50 & 5 \\
\hline
\end{tabular}

\subsubsection{Annual Usage of Machineries}

For a final definition of the cost, it was necessary to identify annual hours of usage; this parameter is dependent on different factors. In fact, a significant part of the cost is due to the amortization of the investment for the purchasing of the machines $(24,000 €$ for the harvester and $70,000 €$ for the pelletizer), which are distributed over the potential machine service-life (respectively, 10 and 15 years). Indeed, the more hours the machine is used in its service-life, the lower the hourly cost will be. Among the factors affecting the annual hours of usage, the following were identified:

1. Biomass yield in the field $\left(\mathrm{t} \mathrm{ha}^{-1}\right)$;

2. Working productivity of the harvester machine, that is, harvestable tons of pruning per hour $\left(\mathrm{th}^{-1}\right)$;

3. Working productivity of the pelleting machine, that is, processable tons of pruning per hour $\left(\mathrm{t} \mathrm{h}^{-1}\right)$;

4. Harvest window due to agronomic and climatic factors.

Whereas the first three factors were measured, the fourth was estimated in a minimal and maximal hypothesis. The maximum hours of annual usage were estimated by considering the potential working days within a harvest window of 90 days, with an effective working time of $8 \mathrm{~h}$ per day. The window of 90 days corresponds to the maximum exploitable period in Italy to collect vineyard pruning, that is, between December (pruning period) and March (first spring tillage) [26]. Within this time interval, some days of inactivity were taken into account to exclude precipitations or unexpected inconveniences. The days of precipitation for the period of January-March were estimated using the regional data of the Regional Agency for Environmental Protection and Prevention (ARPA) of Veneto (http:/ / www.arpa.veneto.it), which provides meteorological data for long historical series. From the database, a mean value of an historical series from 2014 to 2017 was utilized as reference data (38 days of precipitations for the period considered). An additional inactivity period of 2 days was considered to exclude time losses due to unexpected inconveniences (machine breakages, operator sickness, etc.). 
Festivities were not taken into account, as the general habit of contractors in the harvest period is to rest during the raining days. Therefore, in the final estimation of the potential working hours within the 90 days of the harvest window, an effective working period of 50 days was considered as the most reliable for the use of one machine. The minimum hours of annual usage for the pruning harvester were set by considering a threshold below which the collection is no longer sustainable in economic terms, because the hourly harvesting cost would be higher with respect to the agricultural contractor price of $60 € \mathrm{~h}^{-1}$ for pruning shredding [27].

Regarding the pelleting machine, the annual utilization was estimated according to its working capacity $\left(\mathrm{t} \mathrm{h}^{-1}\right)$, considering a working time of $8 \mathrm{~h}$ per day and the minimum and maximum pruning availability as provided by the harvest machine and supply basin.

\section{Results}

\subsection{Harvester and Pelleting Performance}

The total operating time (TO) was strongly affected by the time for unloading (39.8\%), while no rests or delays occurred. The theoretical field speed was $1.31 \mathrm{~m} \mathrm{~s}^{-1}$ and consumptions were $4.23 \mathrm{~L} \mathrm{ha}^{-1}$ (Tables 6 and 7).

Table 6. Working time of the harvester.

\begin{tabular}{ccc}
\hline Parameter & Unit & Value \\
\hline Effective operative time (TE) & $\%$ & $45.55 \pm 2.49$ \\
Turning time & $\%$ & $14.67 \pm 1.28$ \\
Unloading time & $\%$ & $39.78 \pm 1.87$ \\
Maintenance time & $\%$ & 0 \\
Total operating time (TO) & $\%$ & 100 \\
\hline
\end{tabular}

Table 7. Performance and fuel consumption of the harvester.

\begin{tabular}{ccc}
\hline Parameter & Unit & Value \\
\hline Field efficiency & $\%$ & $45.55 \pm 2.49$ \\
Theoretical field speed & $\mathrm{m} \mathrm{s}^{-1}$ & $1.31 \pm 0.06$ \\
Effective field speed & $\mathrm{m} \mathrm{s}^{-1}$ & $0.60 \pm 0.05$ \\
Theoretical field capacity & $\mathrm{ha} \mathrm{h}^{-1}$ & $1.88 \pm 0.09$ \\
Effective field capacity & $\mathrm{ha} \mathrm{h}^{-1}$ & $0.86 \pm 0.08$ \\
Working productivity & $\mathrm{t} \mathrm{h}^{-1}(\mathrm{f.b}) *$. & $1.99 \pm 0.18$ \\
Fuel consumption per tons of harvested pruning & $1 \mathrm{t}^{-1}(\mathrm{f.b})$. & $1.83 \pm 0.06$ \\
Fuel consumption per area worked & $1 \mathrm{ha}^{-1}$ & $4.23 \pm 0.15$ \\
Hourly consumption & $1 \mathrm{~h} \mathrm{~h}^{-1}$ & $3.64 \pm 0.44$ \\
\hline
\end{tabular}

*f.b. = fresh basis.

The harvester worked on windrows $1.30 \pm 0.16 \mathrm{~m}$ wide and $0.35 \pm 0.01 \mathrm{~m}$ high. The amount of biomass collected by the machine was $2.31 \pm 0.16 \mathrm{t} \mathrm{ha}^{-1}$, while harvest losses were $0.39 \pm 0.13 \mathrm{tha}^{-1}$, corresponding to $14.2 \pm 3.92 \%$ of the total potential harvestable pruning.

The productivity of the pelleting system was $371.8 \pm 27.4 \mathrm{~kg} \mathrm{~h}^{-1}$. The mean electricity phase current was $111.3 \pm 15.03 \mathrm{~A}$, and the mean power absorbed by the load was $64.69 \pm 8.74 \mathrm{~kW}$. 


\subsection{Biomass Quality}

After eight months of open-air storage, the moisture content of the chipped material decreased about $50 \%$, passing from $39.9 \%$ to $19.0 \%$. The bulk density showed a reduction from 151.3 to $112.9 \mathrm{~kg} \mathrm{~m}^{-3}$ (Table 8).

Table 8. Bulk density and moisture content of the chipped material before and after the storage.

\begin{tabular}{cccc}
\hline Parameter & Unit & At harvest & Post Storage \\
\hline Bulk density & $\left(\mathrm{kg} \mathrm{m}^{-3}\right)$ & $151.3 \pm 8.3$ & $112.9 \pm 7.4$ \\
Moisture content & $(\%)$ & $39.9 \pm 0.85$ & $19.0 \pm 0.72$ \\
\hline
\end{tabular}

As shown in Figure 3, 87\% of the resulting chips were longer than $50 \mathrm{~mm}$ and distributed mainly in the class 50-100 $\mathrm{mm}(36 \%)$ and $100-120 \mathrm{~mm}(30 \%)$.

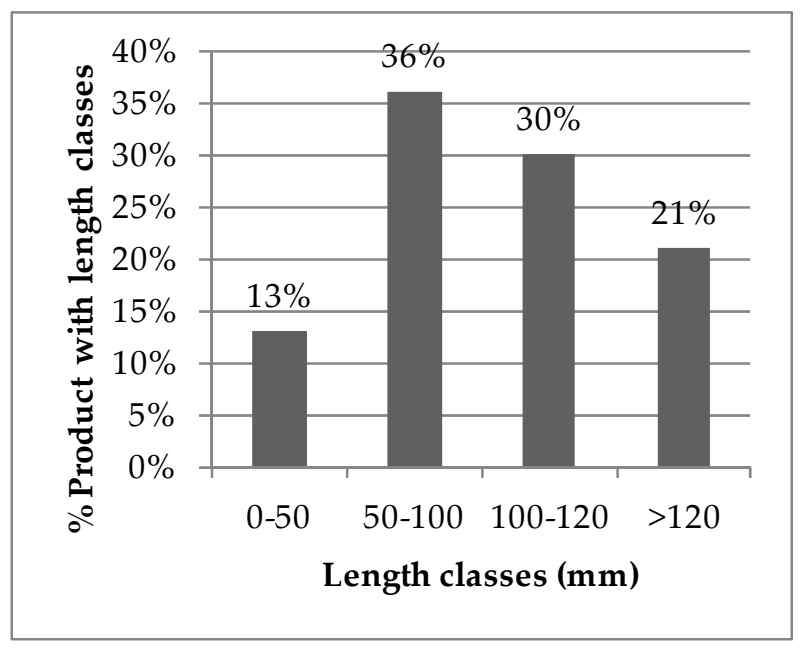

Figure 3. Particle size distribution of chipped material.

Table 9 shows the results obtained in the analysis of pruning and pellet; reference values of typical short rotation coppice pellets as provided by the ISO 17225-1 standard were also furnished. All parameters analyzed complied with the reference values, except for ash content and copper level. Compared to fresh pruning, the ash content and the copper level of the pellet respectively increased by $0.3 \%$ (dry matter basis, $\mathrm{dm}$ ) and $4.4 \mathrm{mg} \mathrm{kg}^{-1} \mathrm{dm}$. From an energetic point of view, pellets improved energy density, keeping a similar net calorific value, increasing bulk density about fivefold and reducing the moisture content of the chipped material threefold.

Table 9. Results of analysis for pellet and pruning with reference values typical for short rotation coppice pellet provided by the ISO 17225-1 standard.

\begin{tabular}{ccccc}
\hline Parameter & Unit & Pellet & Pruning & $\begin{array}{c}\text { Typical Value of Short Rotation } \\
\text { Coppice (1.1.1.3)-ISO 17225-1 }\end{array}$ \\
\hline Moisture content & $\mathrm{w}-\% \mathrm{dm}$ & $6.9 \pm 0.1$ & $39.9 \pm 0.8$ & $\begin{array}{c}\text { Not defined } \\
\text { Ash content }\end{array}$ \\
$\mathrm{w}-\% \mathrm{dm}$ & $4.2 \pm 0.2$ & $3.9 \pm 0.3$ & $0.5-4.0$ \\
Mechanical durability & $\%$ ar & $98.3 \pm 0.1$ & - & Not defined \\
Bulk density & $\mathrm{kg} \mathrm{m}^{-3} \mathrm{ar}$ & $732.2 \pm 9.3$ & - & Not defined \\
Net calorific value & $\mathrm{MJ} \mathrm{kg}{ }^{-1} \mathrm{dm}$ & $17.8 \pm 0.1$ & $18.0 \pm 0.1$ & $17.6-19.0$ \\
Nitrogen & $\mathrm{w}-\% \mathrm{dm}$ & $0.59 \pm 0.03$ & $0.68 \pm 0.5$ & $0.2-1.4$ \\
Chlorine & $\mathrm{w}-\% \mathrm{dm}$ & $0.05 \pm 0.01$ & $0.05 \pm 0.01$ & $0.01-0.18$ \\
Sulphur & $\mathrm{w}-\% \mathrm{dm}$ & $0.03 \pm 0.01$ & $0.03 \pm 0.01$ & $0.01-.11$ \\
Arsenic & $\mathrm{mg} \mathrm{kg}{ }^{-1} \mathrm{dm}$ & $0.12 \pm 0.01$ & $0.18 \pm 0.03$ & $<0.4$ \\
\hline
\end{tabular}


Table 9. Cont.

\begin{tabular}{ccccc}
\hline Parameter & Unit & Pellet & Pruning & $\begin{array}{c}\text { Typical Value of Short Rotation } \\
\text { Coppice (1.1.1.3)-ISO 17225-1 }\end{array}$ \\
\hline Cadmium & $\mathrm{mg} \mathrm{kg}^{-1} \mathrm{dm}$ & $0.15 \pm 0.02$ & $0.07 \pm 0.01$ & $0.2-5$ \\
Copper & $\mathrm{mg} \mathrm{kg}^{-1} \mathrm{dm}$ & $17.2 \pm 1.1$ & $12.8 \pm 2.5$ & $2.0-4.0$ \\
Chromium & $\mathrm{mg} \mathrm{kg}^{-1} \mathrm{dm}$ & $3.2 \pm 0.5$ & $2.3 \pm 0.4$ & $0.3-5$ \\
Mercury & $\mathrm{mg} \mathrm{kg}^{-1} \mathrm{dm}$ & $<0.1$ & $<0.1$ & $<0.03$ \\
Lead & $\mathrm{mg} \mathrm{kg}^{-1} \mathrm{dm}$ & $0.6 \pm 0.1$ & $0.5 \pm 0.1$ & $0.1-2$ \\
Nickel & $\mathrm{mg} \mathrm{kg}^{-1} \mathrm{dm}$ & $0.9 \pm 0.1$ & $1.2 \pm 0.1$ & $0.2-3$ \\
Zinc & $\mathrm{mg} \mathrm{kg}^{-1} \mathrm{dm}$ & $35 \pm 6$ & $27 \pm 4$ & $6-100$ \\
Deformation & ${ }^{\circ} \mathrm{C}$ & $1376 \pm 12$ & $1392 \pm 17$ & Not defined \\
temperature & & & & \\
\hline
\end{tabular}

ar: as received; dm: dry matter.

\subsection{Economic Cost Analysis}

In Scenario A (harvest + in-field drying and pelleting), according to possible supply basins, corresponding pruning availability and annual hours of machineries usage, the harvesting costs were assessed in a variable range from 16.2 to $30.5 € \mathrm{t}^{-1}$, while pelleting costs varied from 115.1 to $146.6 € \mathrm{t}^{-1}$, including ownership and operating costs. Therefore, harvesting affects from $12 \%$ to $17 \%$ of the total costs that varied from 131.3 to $177.1 € \mathrm{t}^{-1}$ (Table 10).

Comparing these results with the reference market price of the commercial A2 pellet, depreciated $10 \%$ $\left(189 € \mathrm{t}^{-1}\right)$, the profit margin goes from 11.9 to $57.7 € \mathrm{t}^{-1}$. Therefore, for in-field pelleting, the minimum profit margin of $30 € \mathrm{t}^{-1}$ will be achieved with a supply basin of about 150 ha. In this regard, as shown in Figure 4, the total cost and the profitability is directly related to the dimension of the supply basin.

The results obtained depend to a large extent on the price of fossil fuels. For instance, assuming a $50 \%$ increase in fossil fuel prices, the total cost for in-field pelleting increases by about $25 €$ per $\mathrm{t}$, almost totally reducing profit margin (Table 11).

Table 10. Pruning harvesting and pelleting costs according to annual hours of machineries usage and supply basin needed (Scenario A).

\begin{tabular}{|c|c|c|c|c|c|c|c|c|}
\hline $\begin{array}{l}\text { Supply } \\
\text { Basin (ha) }\end{array}$ & $\begin{array}{c}\text { Pruning } \\
\text { Availability (t) }\end{array}$ & $\begin{array}{c}\text { Pruning } \\
\text { Harvesting (h) }\end{array}$ & $\begin{array}{l}\text { Harvesting } \\
\text { Cost }\left(€ h^{-1}\right)\end{array}$ & $\begin{array}{l}\text { Harvesting } \\
\text { Cost }\left(€ t^{-1}\right)\end{array}$ & $\begin{array}{l}\text { Pelleting } \\
\text { (h) }\end{array}$ & $\begin{array}{l}\text { Pelleting } \\
\text { Cost }\left(€ h^{-1}\right)\end{array}$ & $\begin{array}{c}\text { Pelleting } \\
\text { Cost }\left(€ t^{-1}\right)\end{array}$ & $\begin{array}{l}\text { Total Cost } \\
\left(€ \mathrm{t}^{-1}\right)\end{array}$ \\
\hline 350 & 805 & 405 & 32.2 & 16.2 & 2165.3 & 42.8 & 115.1 & 131.3 \\
\hline 300 & 690 & 347 & 34.2 & 17.2 & 1856.0 & 43.6 & 117.2 & 134.4 \\
\hline 200 & 460 & 231 & 40.8 & 20.5 & 1237.3 & 46.3 & 124.6 & 145.1 \\
\hline 150 & 345 & 173 & 47.4 & 23.8 & 928.0 & 49.0 & 131.9 & 155.7 \\
\hline 100 & 230 & 116 & 60.7 & 30.5 & 618.7 & 54.5 & 146.6 & 177.1 \\
\hline
\end{tabular}

Table 11. Variation of the minimum and maximum agripellet chain cost (Scenario A), assuming a possible increase of fossil fuel price.

\begin{tabular}{ccccccc}
\hline Cost of Agripellet Chain $\left(\boldsymbol{\in} \mathbf{t}^{-\mathbf{1}}\right)$ & - & $\mathbf{+ 1 0 \%}$ & $\mathbf{+ 2 0} \%$ & $\mathbf{+ 3 0} \%$ & $\mathbf{+ 4 0 \%}$ & $\mathbf{+ 5 0 \%}$ \\
\hline Min & 131.3 & 131.5 & 134.7 & 142.9 & 148.7 & 155.8 \\
Max & 177.1 & 180.3 & 183.9 & 188.7 & 194.3 & 201.4 \\
\hline
\end{tabular}




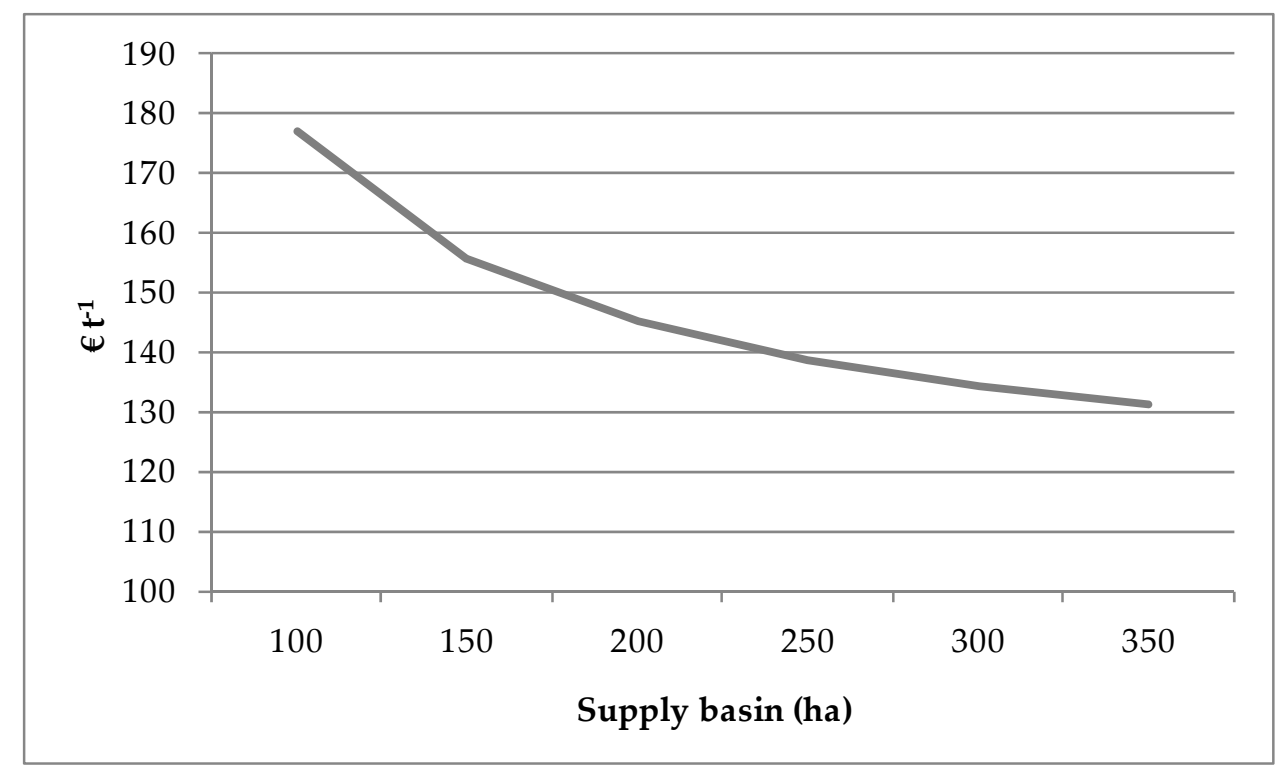

Figure 4. Total pellet production cost according to supply basin.

In Scenario B (pelleting in a centralized site), the transport costs were assessed in $0.53 €$ per $\mathrm{km}$ and ton of biomass transported, as shown in Figure 5.

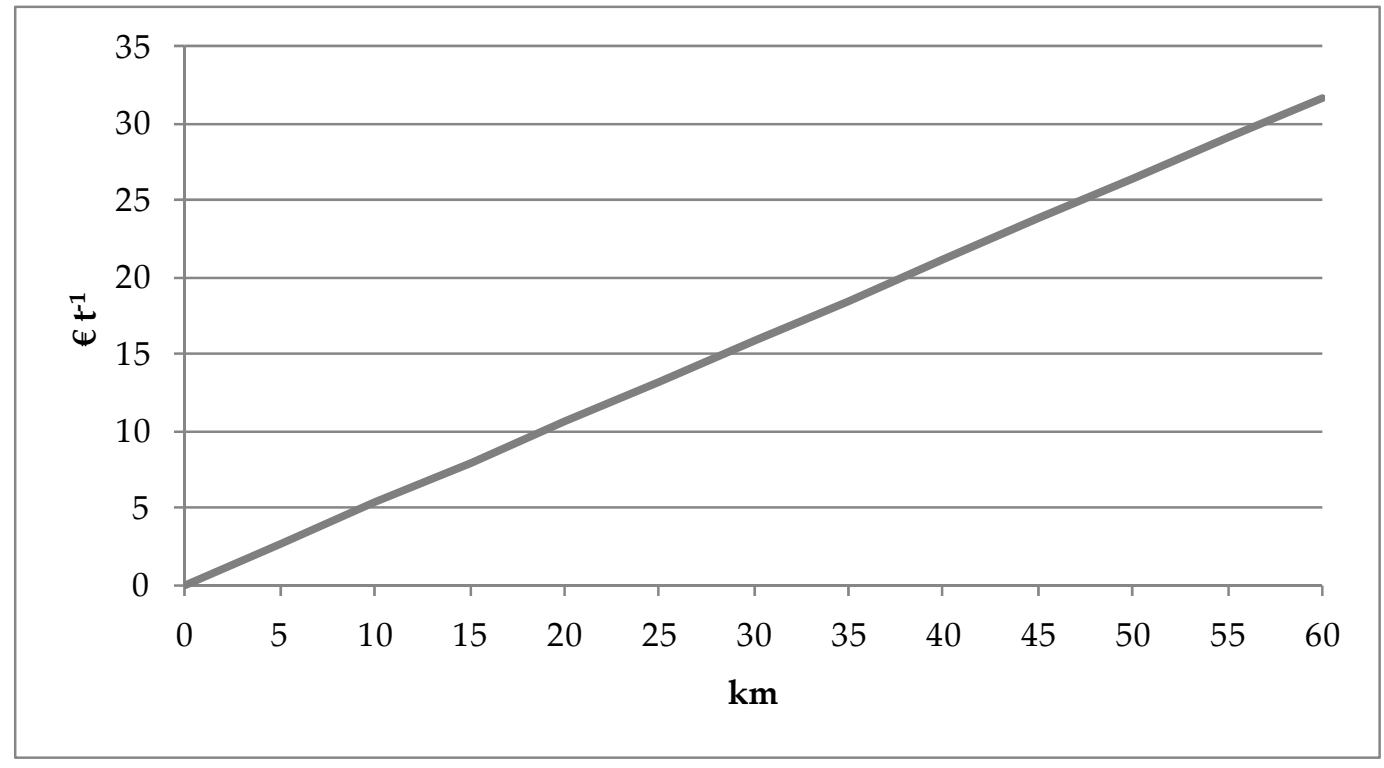

Figure 5. Transport cost $\left(€ \mathrm{t}^{-1}\right)$ according to the distance $(\mathrm{km})$.

Hypothesizing a full exploitation of the harvest machine in the harvest window of three months (16.2€ $\mathrm{t}^{-1}$ cost for harvesting, $115.1 € \mathrm{t}^{-1}$ for pelleting), the total cost, including the transport, reaches the threshold value of $159 € \mathrm{t}^{-1}$ (ensuring a minimal profit margin of $30 € \mathrm{t}^{-1}$ ) at $52.4 \mathrm{~km}$ (Figure 6).

In Scenario C (direct use of the chips, without pelleting), considering a market price of the chips of $50 € \mathrm{t}^{-1}$, a profit margin above $30 € \mathrm{t}^{-1}$ can be achieved only if transport is excluded (selling at the farm site) or if chips are transported within a distance of only $7.2 \mathrm{~km}$ (harvesting + transport cost is $20 € \mathrm{t}^{-1}$ ) (Figure 6). 


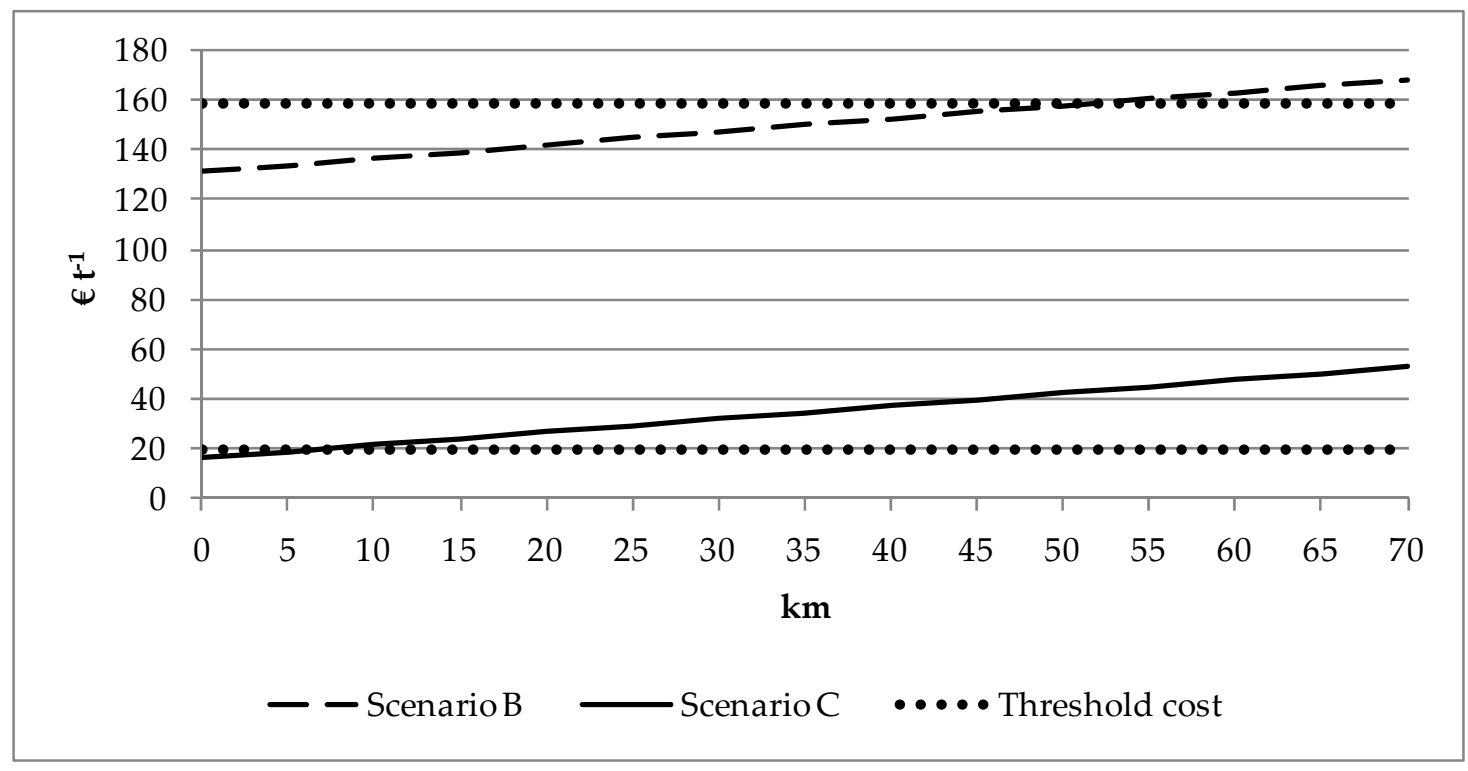

Figure 6. Trend of the production cost including transport in Scenario B (dashed line) and Scenario C (solid line). The crosses with the dotted line indicate the threshold distance of convenience, referring to a minimum profit margin of $30 € \mathrm{t}^{-1}$.

This calculation can change according to the expected profit margin and according to the dimension of the supply basin (availability of biomass). In fact, once a profit margin is fixed, the threshold distance in both Scenario $B$ and $C$ decreases with the reduction of the supply basin dimension. In the case of maximum exploitation, with a supply basin of 350 ha, the profit margin falls below $15 €$ $\mathrm{t}^{-1}$ at transport distance equal to $80.8 \mathrm{~km}$ (Scenario B) and $35.6 \mathrm{~km}$ (Scenario C) or becomes $0 €$ at 109 $\mathrm{km}$ (Scenario B) and $64 \mathrm{~km}$ (Scenario C) (Table 12).

Table 12. Threshold distance of convenience for Scenario A and Scenario B, according to supply basin dimension and expected profit margin.

\begin{tabular}{|c|c|c|c|c|c|c|c|}
\hline \multirow{2}{*}{ Profit Margin $\left(€ t^{-1}\right)$} & \multirow{2}{*}{$\begin{array}{c}\text { Scenario/Threshold } \\
\text { Distance }(\mathbf{k m})\end{array}$} & \multicolumn{6}{|c|}{ Supply Basin (ha) } \\
\hline & & 350 & 300 & 250 & 200 & 150 & 100 \\
\hline \multirow{2}{*}{30.0} & B & 52.4 & 46.6 & 38.5 & 26.4 & 6.3 & np \\
\hline & C & 7.20 & 5.30 & 2.84 & $\mathrm{np}$ & $\mathrm{np}$ & $\mathrm{np}$ \\
\hline \multirow{2}{*}{15} & B & 80.8 & 75.0 & 67.0 & 54.8 & 34.7 & $\mathrm{np}$ \\
\hline & C & 35.6 & 33.7 & 31.3 & 27.5 & 21.2 & 8.52 \\
\hline \multirow{2}{*}{0} & B & 109.2 & 103.4 & 95.3 & 83.2 & 63.1 & 22.6 \\
\hline & $\mathrm{C}$ & 64.0 & 62.1 & 59.7 & 55.9 & 49.6 & 36.9 \\
\hline
\end{tabular}

np: not profitable.

\section{Discussion}

The harvest machine was particularly efficient, generating chips with a particle size distribution $2 / 3$ of which included chips between $50 \mathrm{~mm}$ and $120 \mathrm{~mm}$, even suitable for feeding boilers without pelleting. The regular cut and the good particle size allowed high moisture losses to be reached in a short time during storage, rapidly reaching a value of moisture content which was lower than $20 \%$, allowing direct pelleting and limiting dry matter losses due to microbial degradation. The harvester performance was comparable with other pruning harvesters for theoretical field capacity, but not for field efficiency $[28,29]$. The worst result was strongly affected by the high unloading time, because the machine filled up the small size bin very quickly. This aspect could be improved by elongating the bin or changing the logistics, for example by working with two trailers at opposite sides of the field. 
On the contrary, a lower fuel consumption than other commercial harvesters was achieved thanks to the possibility of using a low power tractor $(50 \mathrm{~kW})$.

Most chemical parameters analyzed in laboratory for pruning and pellet are comparable with the results found in previous studies [30-32]. The main variations refer to heavy metals, due to the different harvesting systems and storage conditions. In particular, the higher copper content is due to both pest-control chemicals applied to vines and to the soil picked up by the harvester. The latter aspect can also explain the higher value respect to raw pruning. Duca et al. [9] demonstrated, in fact, that much of the copper present in biomass is attributable to high presence in the soil. Concerning the moisture content reduction in the open-air pile, the regular cut of the chips and the particle size distribution contributed to the natural drying in by favoring air permeability, as also confirmed by previous studies [21,33].

Regarding the economic assessment, no previous studies were identified to deal with the topic of agripellet production with mobile technologies.

Several studies investigated the cost and marketability of the industrial production of agripellet, in particular from straw. In the Pellets for Europe project [19], the total cost for straw pellet was found to be in a range between 94 and $164 € \mathrm{t}^{-1}$; these results are lower compared to our findings, but they are based on industrial plants. Moreover, prices of straw refer to countries such as Denmark, which have small straw pellets markets.

Javier Sánchez et al. [34] calculated the costs for the whole pellet production chain for vineyard pruning. Only for pelleting, the average cost identified was $56.7 € \mathrm{t}^{-1}$, an amount lower than our estimations, but still referring to an industrial plant. On the other hand, pruning harvest costs were calculated as $19.7 € \mathrm{t}^{-1}$, confirming our findings, but lower than studies performed by Spinelli and Picchi [17], which estimated an average harvesting cost of $28 \mathrm{Et}^{-1}$.

The low costs of harvesting (from $12 \%$ to $17 \%$ of the total costs when storage and pelleting occur directly in the field) at first impact would suggest the convenience to include a second pruning harvester. On the other hand, at maximum exploitation, the use of two harvesters would require the use of two pelleting machines (540 working days), making the economic balance unsustainable. In fact, in the hypothesis of exploiting the harvest machine for the maximum time in the harvest window ( $405 \mathrm{~h}$, i.e., 50 working days), the pelleting machine would work $2165 \mathrm{~h}$ per year (corresponding to 270 working days) to process the whole pruning collected; in this case, an area of about 350 ha would be needed and costs would be minimized at $131 € \mathrm{t}^{-1}$ (Table 10).

As shown, the profitability of the agripellet chain is directly related to the dimension of the supply basin and, with this regard, the characteristics of the Italian farms limit the feasibility of Scenario A. In fact, vineyards are scattered in the national territory and the average size is only 1.96 ha [35]. This implies the need to bring the pruning from several neighboring farms in a centralized site where drying and the pelleting will occur (Scenario B). However, while profitability is guaranteed up to $50 \mathrm{~km}$ in the case of agripellet production, the direct use of the pruning chip (Scenario C), is cost-effective only when the biomass plant is very close to the fields. Nevertheless, the convenience for farmers is identified until a distance of $64 \mathrm{~km}$, just for avoiding costs of field cleaning that are accounted for $60 € \mathrm{~h}^{-1}$ [27].

Basically, the agripellet chain from vineyard pruning in high productive wine areas like the Veneto region can provide a significant amount of additional green economy at local level. This would also reflect a positive social impact of the agripellet chain, which should be added to economic and environmental aspects. A more in-depth assessment should be performed in further studies, allowing for the measurement and comparison of the three dimensions of impacts, accounting for the interlinkages between the environment, economy, and society [36].

\section{Conclusions}

The study suggests that the harvester model MAREV Alba 150 can improve the perspective of using the vineyard pruning residues for the production of biofuels. In addition, vineyard chips 
exhibited good quality parameters, including ash content that was comparable with that of biomass obtained from short rotation forestry. These results are imputable to the pick-up system of the machine, which allowed collecting clean biomass, leaving in the field soil or other inert material.

The pellet generated presents good durability and high bulk density with an energy density of $13 \mathrm{GJ} \mathrm{m}^{-3}$; these are both interesting characteristics for economic and sustainability aspects.

From an economic point of view, the main advantage of the mobile system is to cut down the transport costs of a low density biomass (chips). When pelleting takes place directly in the field, production costs are profitable, with a high economic margin compared to the market price of pellet. Profit margin gradually decreases when chips require to be transported outside the farm (Scenario B) and when the transport distance increases. In any case, the results obtained in this study open up interesting economic opportunities and suggest margins of profits which are higher compared to traditional wood-chip market chains.

Furthermore, the overall advantages of a local production chain, based on the sustainable valorization of residues (currently burned in the field), go beyond economic return. There are environmental and social aspects, not easily measurable, which are worth investigation in further studies.

Author Contributions: G.T. conceived and designed the research; V.A. and A.S. performed the research, analyzed the data, and wrote the paper; L.P. contributed materials/analysis tools.

Funding: This research was funded by the Project SUSCACE (SUpporto Scientifico alla Conversione Agricola alle Colture Energetiche), MIPAAF, D.M. 2419 of 20/02/2008.

Acknowledgments: This work was supported by the Project SUSCACE (SUpporto Scientifico alla Conversione Agricola alle Colture Energetiche), MIPAAF, D.M. 2419 of 20/02/2008.

Conflicts of Interest: The authors declare no conflict of interest.

\section{References}

1. Molino, A.; Larocca, V.; Chianese, S.; Musmarra, D. Biofuels production by biomass gasification: A review. Energies 2018, 11, 811. [CrossRef]

2. Arregi, A.; Amutio, M.; Lopez, G.; Bilbao, J.; Olazar, M. Evaluation of thermochemical routes for hydrogen production from biomass: A review. Energy Convers. Manag. 2018, 165, 696-719. [CrossRef]

3. Scarlat, N.; Dallemand, J.-F.; Monforti-Ferrario, F.; Banja, M.; Motola, V. Renewable energy policy framework and bioenergy contribution in the European Union-An overview from National Renewable Energy Action Plans and Progress Reports. Renew. Sustain. Energy Rev. 2015, 51, 969-985. [CrossRef]

4. European Commission State of Play on the Sustainability of Solid and Gaseous Biomass Used for Electricity, Heating and Cooling in the EU-Commission Staff Working Document. 2014. Available online: http: / / ec.europa.eu/transparency/regdoc/rep/10102/2014/EN/10102-2014-259-EN-F1-1.PDF (accessed on 6 August 2018).

5. Oh, Y.K.; Hwang, K.R.; Kim, C.; Kim, J.R.; Lee, J.S. Recent developments and key barriers to advanced biofuels: A short review. Bioresour. Technol. 2018, 257, 320-333. [CrossRef] [PubMed]

6. European Commission Proposal for a Directive of the European Parliament and of the Council on the Promotion of the Use of Energy from Renewable Sources. Available online: https:/ / eur-lex.europa.eu/ resource.html?uri=cellar:151772eb-b7e9-11e6-9e3c-01aa75ed71a1.0001.02/DOC_1\&format=PDF (accessed on 6 August 2018).

7. European Parliament resolution of 5 February 2014 on a 2030 Framework for Climate and Energy Policies. A 2030 Framework for Climate and Energy Policies. 2014. Available online: http:/ / www.europarl.europa.eu/ sides/getDoc.do?pubRef=- / /EP / /NONSGML+TA+P7-TA-2014-0094+0+DOC+PDF+V0//EN (accessed on 6 August 2018).

8. Stelte, W.; Sanadi, A.R.; Shang, L.; Holm, J.K.; Ahrenfeldt, J.; Henriksen, U.B. Recent developments in biomass pelletization-A review. BioResources 2012, 7, 4451-4490.

9. Duca, D.; Toscano, G.; Pizzi, A.; Rossini, G.; Fabrizi, S.; Lucesoli, G.; Servili, A.; Mancini, V.; Romanazzi, G.; Mengarelli, C. Evaluation of the characteristics of vineyard pruning residues for energy applications: Effect of different copper-based treatments. J. Agric. Eng. 2016, 47, 22. [CrossRef] 
10. García-Galindo, D.; López, E.; Gómez, M.; Sebastián, F.; Gebresenbet, G.; Jirjis, R.; Kern, J.; Germer, S.; Pari, L.; Suardi, A.; Dyjakon, A.; et al. Europruning Project: Summary of Final Results. Available online: http:/ / www.etaflorence.it/proceedings/?detail=13021 (accessed on 20 July 2018).

11. Picchi, G.; Silvestri, S.; Cristoforetti, A. Vineyard residues as a fuel for domestic boilers in Trento Province (Italy): Comparison to wood chips and means of polluting emissions control. Fuel 2013, 113, 43-49. [CrossRef]

12. EC Eurostat Database. European Commission Online Statistical Database. 2017. Available online: https: / / ec.europa.eu/eurostat (accessed on 20 July 2018).

13. ISTAT Istat Database. Istituto Nazionale di Statistica Online Statistical Database. 2017. Available online: https:/ / www.istat.it/it/agricoltura (accessed on 20 July 2018).

14. Motola, V.; Colonna, N.; Alfano, V.; Gaeta, M.; Sasso, S.; De Luca, V.; De Angelis, C.; Soda, A.; Braccio, G. Censimento Potenziale Energetico Biomasse, Metodo Indagine, Atlante Biomasse su WEB-GIS. Available online: http://editors.enea.it/it/Ricerca_sviluppo/documenti/ricerca-di-sistema-elettrico/ censimento-biomasse/rse167.pdf (accessed on 20 July 2018).

15. ISO 17225-1:2014—Solid Biofuels_Fuel Specifications and Classes_Part 1: General Requirements; International Organization for Standardization: Geneva, Switzerland, 2014.

16. ISO 17225-6:2014-Solid Biofuels_Fuel Specifications and Classes_Part 6: Graded Non-Woody Pellets; International Organization for Standardization: Geneva, Switzerland, 2014.

17. Spinelli, R.; Magagnotti, N.; Nati, C. Harvesting vineyard pruning residues for energy use. Biosyst. Eng. 2010, 105, 316-322. [CrossRef]

18. Zeng, T.; Weller, N.; Lenz, V. Mixbiopells: Enhancing the market relevance of alternative (mixed) biomass pellets in Europe. 19th Eur. Biomass Conf. Exhib. 2011, 306-314. [CrossRef]

19. Pellets in Southern Europe. The State of the Art of Pellets Utilisation in Southern Europe. New Perspectives of Pellets from Agri-Residues. Available online: https://www.researchgate.net/profile/Theocharis Tsoutsos2/publication/263357353_PELLETS_IN_SOUTHERN_EUROPE_THE_STATE_OF_THE_ART_ OF_PELLETS_UTILISATION_IN_SOUTHERN_EUROPE_NEW_PERSPECTIVES_OF_PELLETS_FROM_ AGRI-RESIDUES/links/0c96053aa9da7f323b000000/PELLETS-IN-SOUTHERN-EUROPE-THE-STATEOF-THE-ART-OF-PELLETS-UTILISATION-IN-SOUTHERN-EUROPE-NEW-PERSPECTIVES-OFPELLETS-FROM-AGRI-RESIDUES.pdf (accessed on 6 August 2018).

20. Pari, L.; Suardi, A.; Santangelo, E.; García-Galindo, D.; Scarfone, A.; Alfano, V. Current and innovative technologies for pruning harvesting: A review. Biomass Bioenergy 2017, 107, 398-410. [CrossRef]

21. Pari, L.; Scarfone, A.; Santangelo, E.; Gallucci, F.; Spinelli, R.; Jirjis, R.; Del Giudice, A.; Barontini, M. Long term storage of poplar chips in Mediterranean environment. Biomass Bioenergy 2017, 107, 1-7. [CrossRef]

22. Bodria, L.; Pellizzi, G.; Piccarolo, P. Meccanica Agraria vol II: La Meccanizzazione; Il Sole 24 Ore Edagricole: Bologna, Italy, 2006; ISBN 8850651325.

23. Whittaker, C.; Shield, I. Factors affecting wood, energy grass and straw pellet durability-A review. Renew. Sustain. Energy Rev. 2017, 71, 1-11. [CrossRef]

24. Biomasse Legnose: Petrolio Verde per il Teleriscaldamento. Available online: http://www.fiper.it/uploads / media/invito-fiper-politecnico.pdf (accessed on 6 August 2018).

25. Costo di Esercizio Delle Macchine Agricole. Available online: http:/ /www.informatoreagrario.it/ita/files / 06-Costi-Mazzetto.pdf (accessed on 6 August 2018).

26. Veneto Agricoltura Gestione del Suolo. In Guida per il Viticoltore; Azienda Regionale Veneto Agricoltura: Legnaro, Italy, 2004; p. 94. Available online: http:/ /www.venetoagricoltura.org/2007/01/editoria/guidaper-il-viticoltore-2004librocod-sc106esaurito/ (accessed on 6 August 2018).

27. Unione Nazionale Contoterzisti Agromeccanici e Industriali Tariffe per Lavori di Meccanizzazione Agricola 2015. Available online: http:/ /www.contoterzisti.it/tariffe/TARIFFARIO\%20UMBRIA.pdf (accessed on 6 August 2018).

28. Recchia, L.; Daou, M.; Rimediotti, M.; Cini, E.; Vieri, M. New shredding machine for recycling pruning residuals. Biomass Bioenergy 2009, 33, 149-154. [CrossRef]

29. Spinelli, R.; Nati, C.; Pari, L.; Mescalchin, E.; Magagnotti, N. Production and quality of biomass fuels from mechanized collection and processing of vineyard pruning residues. Appl. Energy 2012, 89, 374-379. [CrossRef] 
30. Zanetti, M.; Brandelet, B.; Marini, D.; Sgarbossa, A.; Giorio, C.; Badocco, D.; Tapparo, A.; Grigolato, S.; Rogaume, C.; Rogaume, Y.; et al. Vineyard pruning residues pellets for use in domestic appliances: A quality assessment according to the EN ISO 17225. J. Agric. Eng. 2017, 48, 99. [CrossRef]

31. Picchi, G.; Lombardini, C.; Pari, L.; Spinelli, R. Physical and chemical characteristics of renewable fuel obtained from pruning residues. J. Clean. Prod. 2018, 171, 457-463. [CrossRef]

32. Manzone, M.; Paravidino, E.; Bonifacino, G.; Balsari, P. Biomass availability and quality produced by vineyard management during a period of 15 years. Renew. Energy 2016, 99, 465-471. [CrossRef]

33. Jirjis, R. Effects of particle size and pile height on storage and fuel quality of comminuted Salix viminalis. Biomass Bioenergy 2005, 28, 193-201. [CrossRef]

34. Javier, S.L.; de la Mora, C.F.M.D.; Marina, S.G.; Jesus, F.G. A proposal for pellet production from residual woody biomass in the island of Majorca (Spain). AIMS Energy 2015, 3, 480-504. [CrossRef]

35. Indagine Sulla Struttura e Produzioni Delle Aziende Agricole-2013. Available online: http://www. regione.lazio.it/binary/prtl_statistica/statistica_SPAA_argomenti/questionario_SPA_2013.pdf (accessed on 6 August 2018).

36. Van Schoubroeck, S.; Van Dael, M.; Van Passel, S.; Malina, R. A review of sustainability indicators for biobased chemicals. Renew. Sustain. Energy Rev. 2018, 94, 115-126. [CrossRef]

(C) 2018 by the authors. Licensee MDPI, Basel, Switzerland. This article is an open access article distributed under the terms and conditions of the Creative Commons Attribution (CC BY) license (http:/ / creativecommons.org/licenses/by/4.0/). 